University of Nebraska - Lincoln

DigitalCommons@University of Nebraska - Lincoln

Sociology Department, Faculty Publications

Sociology, Department of

1993

\title{
A Comparison of Adaptive Strategies and Patterns of Victimization among Homeless Adolescents and Adults
}

Les B. Whitbeck

University of Nebraska-Lincoln, Iwhitbeck2@unl.edu

Ronald L. Simons

lowa State University, rsimons@uga.edu

Follow this and additional works at: https://digitalcommons.unl.edu/sociologyfacpub

Part of the Sociology Commons

Whitbeck, Les B. and Simons, Ronald L., "A Comparison of Adaptive Strategies and Patterns of Victimization among Homeless Adolescents and Adults" (1993). Sociology Department, Faculty Publications. 112.

https://digitalcommons.unl.edu/sociologyfacpub/112

This Article is brought to you for free and open access by the Sociology, Department of at DigitalCommons@University of Nebraska - Lincoln. It has been accepted for inclusion in Sociology Department, Faculty Publications by an authorized administrator of DigitalCommons@University of Nebraska - Lincoln. 


\title{
A Comparison of Adaptive Strategies and Patterns of Victimization among Homeless Adolescents and Adults
}

\author{
Les B. Whitbeck and Ronald L. Simons \\ Department of Sociology, Iowa State University
}

\begin{abstract}
One hundred and fifty-six homeless adolescents and 319 homeless adults interviewed directly on the streets and in shelters were compared for backgrounds of abuse, adaptations to life on the streets, and rates of criminal victimization when on the streets. Homeless adolescents were more likely to be from abusive family backgrounds, more likely to rely on deviant survival strategies, and more likely to be criminally victimized. A social learning model of adaptation and victimization on the streets was hypothesized. Although the model was supported for both homeless adults and adolescents, it was more strongly supported for adolescents than adults, and for males than females regardless of age.
\end{abstract}

$\mathrm{T}$ here has been extensive documentation of the dangers and hardships faced by those who find themselves homeless in our society. Over and above the fundamental vulnerability of being without a safe and private place to live and rest (Jahiel, 1987), living on the streets or in shelters is replete with day-to-day threats to physical and psychological well-being (Hope \& Young, 1986). Physical threats abound both on the streets and in shelters (Committee on Health Care for Homeless People, 1988). Many homeless persons prefer the uncertainty of the streets to often overcrowded and poorly supervised public shelters (Hope \& Young, 1986; Jahiel, 1987; Stefl. 1987). The psychological consequences of continual vulnerability to physical harm, exhaustion, poor nutrition, and the stress of living in public places serve to create psychological distress or exacerbate existing-psychological problems (Bassuk, 1986; Ropers, 1988; Simons \& Whitbeck. 1989).

Although homelessness is not new (Hopper \& Hamberg, 1986; Moment, 1989), there is general consensus that during the past decade the number of homeless people has increased, and the character of the group has changed (Stepfl, 1987). The new homeless are a diverse group, made up of individual adults, youth, and families (Baxter \& Hopper, 1984; Committee on Health Care for Homeless People, 1988). With the diversity of those 
who find themselves living on the streets or in shelters comes a diversity of adaptation strategies and risks. Separate street cultures may exist side by side, with little intermingling, and profoundly different survival experiences. Little research, however, explicitly compares the experiences on the streets of diverse groups. The present research contrasts survival strategies and victimization among homeless adolescents and adults.

\section{Homeless Adolescents}

Estimates of the number of runaway or throwaway youth on the streets are scarce (Committee on Health Care for Homeless People, 1988) and vary widely. The House Subcommittee on the Constitution has estimated that almost two million youths run away each year. In 1984, the Department of Health and Human Services estimated that up to 1.3 million youths had run away, and that 500,000 of these youths were, for all intents and purposes, homeless (Janus, McCormick, Burgess, \& Hartman, 1987). According to Nye and Eldelbrock (1980), one child in eight will run away prior to age 18 years. This projection almost doubles for single parent households and households with more than eight persons. Janus et al. report that in 1985, “271 shelters provided 60, 500 youths with residential services, drop-in services aided 305,500, and hotline services were used by 250,000 youths" (1987, p. 12). Although they constitute a significant proportion of those on the street, most of the research on homeless youth is based on small samples, and often relies on anecdotal evidence. For example, the Committee on Health Care for Homeless People (1988) base their analysis of health risk and needs of homeless adolescents on three studies with samples of 84,118 , and 149 .

The work that has been done on adolescent homeless, however, reveals a stark and dangerous picture of life on the streets. Unlike romantic characterizations of runaways in the past, contemporary homeless adolescents are typically running away from something, rather than running toward something (Janus, et al. 1987). Brennan, Blanchard, Huizinga, and Elliott (1975) reported that runaways who stayed away from home longer than 3 months were much more apt to report physical abuse, parental rejection, and lack of monitoring by parents, than young people who ran away for shorter periods of time. McCormack, Burgess, and Gaccione (1986) found that $67 \%$ of a sample of 87 males and female runaways reported physical abuse, and $44 \%$ reported sexual abuse. Janus, et al., report that of 135 runways, 43\% gave physical abuse as an important reason for running away. From a sample of 84 homeless youth, Whitbeck and Simons (1990) found that $47 \%$ reported being beaten by a parent, foster parent, or adult relative, and $30 \%$ reported sexual abuse. The rates of abuse among this sample of homeless youth were many times those for the Straus and Gelles (1990) national probability sample.

Adolescents find that street life simply substitutes new risks of victimization for old ones. Because there are few, if any, legitimate means of support for homeless young people, subsistence strategies often involve deviant or risky behaviors such as panhandling, shoplifting, selling drugs, theft, or selling sexual favors (Hersch, 1988, Janus, et al. 1987; Simons \& Whitbeck, 1991; Whitbeck \& Simons, 1990). Spending time on the streets also increases risk by increasing the likelihood of affiliation with deviant peers who may serve both to socialize antisocial behaviors and to directly exploit one another (Whitbeck \& Simons, 1990). 
Day to day life on the streets coupled with reliance on deviant, often risky, subsistence strategies serve to greatly increase the probability of victimization for homeless adolescents. Janus et al. (1987) refer to case histories in their sample of 149 homeless youth involving prostitution, assault, drug use and exploitation. Hersch (1988) describes the constant threat of assault and sexual exploitation for young people on the street. Whitbeck and Simons (1990) found that $40 \%$ of their sample of 84 street youth had been beaten up on the streets, $43 \%$ of the young women had been raped, and over half of the young men had been threatened with a weapon of some kind.

In summary, homeless adolescents usually bring a history of victimization to the streets, and find nothing in their new independence that softens their view of reality. They find a system of equally damaged peers and exploitive adults, a need to learn new, often dangerous skills to survive, and a high risk of further victimization.

\section{Homeless Adults}

While homeless adolescents are similar in age and share flight as the common reason for their homelessness, homeless adults are a more heterogeneous group. Estimates regarding the number of homeless adults and the reasons for homelessness vary widely and have been the subject of much debate. Estimates range from 250, 000 to 350, 000 homeless people on an average night (Peroff. 1987). There is general agreement that this number is not made up of the typical skid row, alcoholic male. Rather, the Department of Housing and Urban Development estimates that although the vast majority of shelter users are men, $13 \%$ are single women, and $21 \%$ are family members (Department of Housing and Urban Development, 1984).

Adults become homeless for a variety of reasons: loss of housing, low paying or loss of jobs, domestic violence, mental illness, and substance abuse (committee on Health Care for Homeless People. 1988; Roper, 1988; Stefl, 1987).

Because of varying levels of resources and disability, the experience of homelessness for adults may be very different. Homelessness may mean a chronic rotation of temporary shelters from single room occupancy hotels, to public shelters or the streets when the money runs out, and back to substandard hotels with the arrival of a benefit check at the first of the month (Roper, 1988). Conversely, it may involve a long term adaptation to living directly on the streets, eking out a living by panhandling, scrounging food, and selling blood. The type of adaptation to homelessness will affect the degree of risk. While all homelessness implies vulnerability, subsistence strategies serve to exacerbate or decrease exposure to potential harm.

\section{Theoretical Background}

Living one's day to day life in public increases the risk of physical and psychological harm. Life-style/exposure theory (Hindelang, Gottfredson, \& Garafola, 1978) suggests that persons are particularly vulnerable to criminal victimization when their life-styles lead them to spend large amounts of time in public places such as the streets or parks, especially at night. Life-styles include such things as one's daily activities, patterns of leisure 
and work which characterize a person's social position. Groups of people adopt day-today routines consistent with their levels of economic, social, and psychological resources. It follows from life-style/exposure theory that homeless people are at particular risk for criminal victimization. The public location of their daily lives places them in jeopardy.

However, factors other than location serve to heighten potential risk. Behaviors on the streets also contribute to the likelihood of harm. Whitbeck and Simons have shown that among both homeless adolescents and adults, survival strategies were strongly related to victimization (Simons. Whitbeck. \& Bales. 1989; Whitbeck \& Simons. 1990). Homeless persons who relied on deviant survival strategies such as selling drugs, shoplifting, petty theft, and selling sexual favors were at much greater risk of victimization. Social learning theory is helpful in understanding the antecedents of risky behaviors and the link between deviant subsistence strategies and harm.

Patterson's social learning approach to adolescent deviance is especially informative in this regard (Patterson. 1982, 1986; Patterson \& Bank. 1987). Patterson has shown that coercive, aggressive parenting, characterized by harsh disciplinary techniques elicit aggressive responses in children. The children's aggressive responses, in turn, rouse negative reactions from parents which result in "coercive chains" where one party attempts to control the other. These coercive interchanges greatly increase the likelihood of physical abuse. Patterson terms these family interaction patterns "basic training" for antisocial behavior. Such interaction styles tend to be generalized to other settings resulting, in turn, in aggressive or rejecting responses. There is strong and consistent evidence that poor parenting practices and abuse contribute to running away (Brennan et al., 1975; Janus et al., 1987; Whitbeck \& Simons, 1990), delinquency (Patterson, Dishion, \& Bank, 1984; Patterson \& Stouthamer-Loeber, 1984 ), and substance abuse (Dishion \& Loeber, 1985). A social learning approach to the victimization of homeless persons proposes that early "basic training" for aggressive behaviors in coercive, aggressive families results in the greater likelihood of a history of deviant behaviors. This history of deviant behaviors will increase the likelihood of deviant subsistence strategies when on the streets, which, in turn, increase the likelihood of victimization.

\section{Hypothesis}

\section{Age-Related Differences in Risk of Victimization}

First, because homeless adults have a wider variety of adaptive strategies and resources than do homeless adolescents, it was proposed that risks of victimization between the two groups would vary. Adolescents tend to be on the streets because they are running from something (Janus et al. 1987), usually from a dysfunctional or abusive household. Adolescents, therefore, fit the proposed social learning model more readily. Adults, on the other hand, are on the streets for a multiplicity of reasons (Bassuk \& Rosenberg, 1988; Weitzman, Knickman, \& Shinn, 1990). They also have a greater variety of subsistence strategies available to them. Adults may qualify for benefits or supports which are simply unavailable to adolescents because of their status as runaways or throwaways. Adults may also engage in other, more legitimate means of support, such as selling blood or part time work, which are less accessible to adolescents. Among adults, therefore, only 
a small subgroup of the homeless population, those from abusive backgrounds, are expected to fit the social learning model.

The present research compared the subsistence strategies among homeless adolescents and adults. Based on previous research, it was hypothesized that: 1) homeless adolescents would more likely be from abusive family backgrounds than adult homeless, and, 2) homeless adolescents would more likely be involved in deviant subsistence strategies such as selling drugs, shoplifting, petty theft, and prostitution than homeless adults. Because their involvement in deviant subsistence strategies places adolescents at greater risk, it was also hypothesized that adolescents would more likely be criminally victimized when on the streets than homeless adults.

\section{Models of Adaptation to Life on the Street}

Second, a social learning approach to the victimization of homeless adolescents and adults was proposed (Figure 1). Based on Patterson's use of a social learning explanation for the development and persistence of antisocial behaviors, it was hypothesized that a history of abuse in the family would be positively related to a history of antisocial conduct as evidenced by involvement with the legal system. In turn, both a history of abuse and a history of antisocial behaviors were predicted to be positively related to deviant subsistence strategies when living on the streets. Finally, deviant subsistence strategies were hypothesized to be positively related to victimization on the streets.

The models proposed that early victimization in the form of child abuse puts a negative chain of events in motion by affecting behaviors and interaction styles that increases the person's vulnerability for victimization in other contexts. Individuals who have been socialized to be aggressive and expect aggression from others are more likely to exhibit behaviors that place them at risk for further victimization.

In summary, this research proposed two sets of hypotheses. The first predict age related differences in victimization rates and risk behaviors in the form of deviant subsistence strategies. The second set of hypotheses proposed a developmental model that predicts those most likely to make high risk adaptations to living on the street, and, hence, be at greatest risk of victimization.

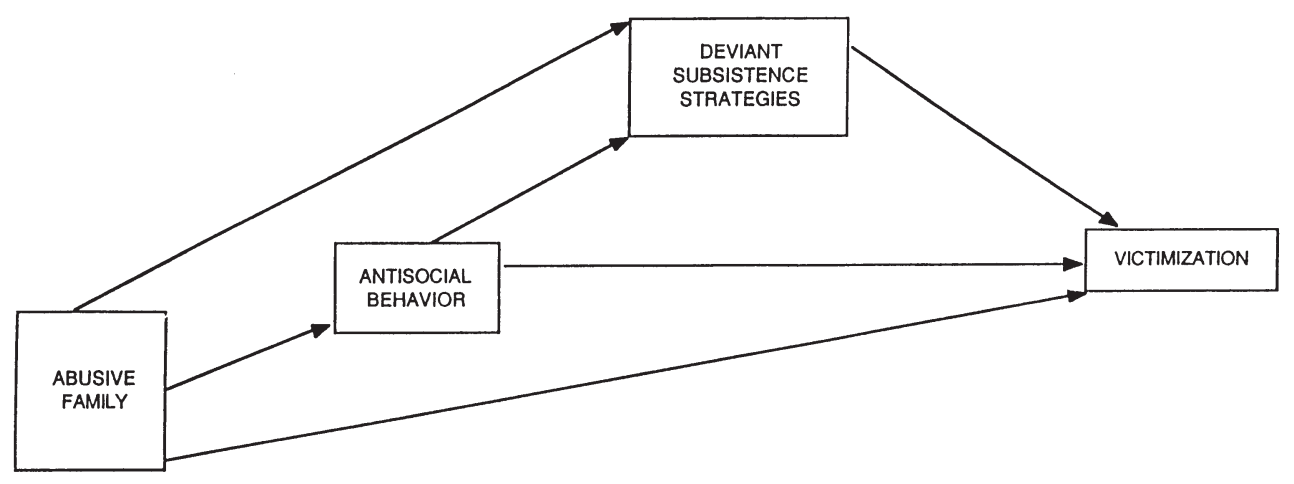

Figure 1. Social Learning Model of Victimization on the Streets 


\section{Method}

The sample was made up of 319 homeless adults and 156 homeless adolescents interviewed directly on the streets and in shelters in a Midwestern city of about 250,000 people. This was an availability sample of all of the respondents who could be contacted by street workers affiliated with agencies who worked with homeless youth or homeless adults. Street workers requested interviews with individuals engaged as pan of their routine outreach duties such as passing out coffee and sandwiches, and offering shelter and referrals for services. In addition, interviewers approached adult homeless people in various shelters. All the interviewers were asked to keep track of the refusals. Their reports of attempted contacts and successful interviews indicated a response rate of approximately $80 \%$ for adolescents and $90 \%$ for adults. Respondents received a token reimbursement of $\$ 2.00$ for participating in the interview. The sample was not stratified by those living in shelters and those living on the street Although the data are from self-reports of troubling and often illegal behavior, research evidence suggests that under similar confidential conditions such reports are quite reliable (Hindelang, Hirschi. \& Weiss. 1981).

\section{Adolescents}

Eighty-three adolescent males and 73 females between the ages of 14 and 18 years were interviewed directly on the streets and in youth shelters. The adolescent sample was made up only of runaway youth and does not include adolescents who are members of families where the parents have become homeless. The youths were $83 \%$ White, with the rest being of Black, Hispanic, or Native American descent Seventy percent of the youth said they were from a city of over 100,000 people, about $10 \%$ were from towns of 10,000 or less, with just over $5 \%$ from rural communities. Twenty-eight percent reported that their fathers had not completed high school, 31\% had fathers who had completed high school, $25 \%$ said their fathers had some college or training after high school, and $16 \%$ of the fathers were college graduates. The educational level of mothers was similar. Twenty- five percent of the youths' mothers had not completed high school, 36\% had finished high school, 20\% had some college or training beyond high school, and 18\% had graduated from college. Seventeen percent of the youth reported that they were from father-absent families. Adolescents were asked where they had spent most of their time during the past year. As shown in Table 1, their primary living arrangements varied a great deal. About one-third had spent most of the previous year with parents, and $20 \%$ had lived with a friend before running away. Only about 3\% lived independently, and about 7\% had spent most of the previous year on the street. The youth were much more apt to have run from a group home than a foster home.

In response to a check list generated in a pretest of runaway adolescents, the respondents gave numerous reasons for running away (Table 2). One-third indicated that "parents being too strict" was an important or somewhat important reason for running away. Another one-third gave physical abuse or violence in the home as a reason for leaving. Sexual abuse was indicated as a reason for running away by $25 \%$ of the young women. Almost $30 \%$ of the respondents reported that their parents did not care about them. Another $30 \%$ reported that they were in trouble and were afraid to go home. Almost one-half the males and one-third of the females gave "looking for excitement" as a reason for leaving home. Over one-third said they "went with a friend." Thirty-four percent of the males compared 
to $11 \%$ of the females cited "legal troubles" as a reason for being on the streets. About onefourth said that school troubles contributed to their decision to run away; Almost $70 \%$ of the youth had run away 3 or more times. One-third reported running away more than 10 times. Sixty percent of the youth reported that they had been "barred from home" by their parents. Adolescent males (67\%) were somewhat more likely to report that they could not return home than were females (51 \%). Forty-five percent of the youth had been away from home for more than 50 days, an additional 13\% had been away for 21-50 days.

Table 1. Living Situations in which Adolescent Spent the Most Time during Past Year from Time of Interview

\begin{tabular}{|c|c|c|c|}
\hline $\mathrm{N}=$ & $\begin{array}{c}\text { Percent } \\
\text { Total } \\
156\end{array}$ & $\begin{array}{c}\text { Percent } \\
\text { Males } \\
83\end{array}$ & $\begin{array}{c}\text { Percent } \\
\text { Females } \\
73\end{array}$ \\
\hline Home with parents or guardian & 32.7 & 35.0 & 30.0 \\
\hline Relative other than parent & 7.3 & 5.0 & 10.0 \\
\hline Friend's home & 22.7 & 21.2 & 24.3 \\
\hline Foster home & .7 & - & 1.4 \\
\hline Group home & 12.0 & 12.5 & 11.4 \\
\hline Correction facility & 6.0 & 8.7 & 2.9 \\
\hline $\begin{array}{l}\text { Independent living situation } \\
\text { (with other youths) }\end{array}$ & 3.3 & 2.5 & 4.3 \\
\hline On the street & 6.7 & 6.3 & 7.1 \\
\hline $\begin{array}{l}\text { Other institution (e.g. mental } \\
\text { hospital, boarding school) }\end{array}$ & 4.7 & 2.5 & 7.1 \\
\hline Other adult (nonrelative) & 2.0 & 3.7 & 1.4 \\
\hline
\end{tabular}

Table 2. Reasons for Running Away

\begin{tabular}{lccc}
\hline & $\begin{array}{c}\text { Percent } \\
\text { Total } \\
(\mathrm{N}=156)\end{array}$ & $\begin{array}{c}\text { Percent } \\
\text { Males } \\
(\mathrm{N}=83)\end{array}$ & $\begin{array}{c}\text { Percent } \\
\text { Females } \\
\text { (Very important or somewhat important) }\end{array}$ \\
\hline Parents too strict & 32.2 & 32.5 & 31.9 \\
Physical abuse & 28.7 & 23.7 & 34.3 \\
Sexual abuse & 17.1 & 12.3 & 25.4 \\
Violence in home & 37.3 & 38.7 & 35.8 \\
Parent mentally ill & 9.6 & 5.7 & 22.7 \\
Parent did not care about me & 29.4 & 30.3 & 28.2 \\
In trouble and afraid to go home & 30.5 & 30.3 & 30.8 \\
Trouble at school & 24.7 & 28.2 & 20.6 \\
Not passing at school & 16.0 & 16.0 & 15.9 \\
Trouble with friends & 10.6 & 10.8 & 10.3 \\
Legal trouble & 23.2 & 33.8 & 10.8 \\
Looking for excitement & 41.4 & 48.1 & 33.8 \\
Went with a friend & 36.6 & 38.2 & 34.8 \\
\hline
\end{tabular}

* Duplicate count, columns do not add to 100. 


\section{Adults}

The adult sample consisted of 224 men and 95 women, ranging in age from 18 to 65 years. The adults were interviewed by street workers directly on the street and in homeless shelters for men and women. Battered women's shelters were not included in the sampling frame which means that women with long abuse histories may be under- represented. Eighty percent of the respondents were White, with the remainder being Black, Hispanic, and Native American. As a group, they were well below national averages for education. Forty percent had not completed high school, 33\% were high school graduates, with the remaining having had at least some college education. Most of the people interviewed had been homeless for some time. Seventy-one percent had been homeless for 6 months or more, one-third had been homeless for longer than five years. Most were from urban backgrounds, two-thirds had lived in a city with a population of more than 100,000 people prior to becoming homeless. The majority of the adult respondents had not been employed for a considerable length of time. Only $9 \%$ had steady employment in the recent past. Although one-third said that they had "worked more than not over the last few years," another onethird reported that they had "rarely worked over the last few years." Forty-five percent of the men were veterans; sixteen percent had served in Vietnam. Less than 10\% were receiving any type of regular income from social security, SSI, Veteran's Benefits, pensions, or the like. Women were somewhat more likely to be receiving benefits of some type than were men. Although the majority of those interviewed had spent the previous night in a shelter of some sort, this was more likely for women (95\%) than for men (73\%).

As expected, the adults gave diverse reasons for being on the streets. Twenty-two percent gave an alcohol or drug problem as the reason for being homeless, $26 \%$ said they were homeless because of an inability to cope with a life crisis, $21 \%$ said homelessness had been brought about by a major economic setback, $7 \%$ were migrant workers between jobs, and $4 \%$ gave mental illness as the reason for being on the streets, with the remainder falling into various categories such as "likes the life", just got out of prison, etc.

\section{Measurement}

Physical abuse was measured by eleven items for runaway youth and nine items for adults. All of the items were from the Straus and Gelles (1990) measures of family violence, with addition of sexual abuse items. Adolescent respondents were asked how often a parent, foster parent, or adult relative had thrown something at them in anger, slapped them, spanked them, hit them with an object, beat them, threatened them with a weapon, or assaulted them with a weapon. In addition to the Straus and Gelles measures of physical abuse, adolescents were asked whether a parent, foster parent, or adult relative had made verbal request for sexual activity, touched or attempt to touch them sexually, or forced them to engage in sexual activities against their wills. Response categories ranged from $1=$ never to $4=$ more than 3 times. Cronbach's alpha reliability coefficient for the adolescent scale was 86 .

The adult measure of abuse was similar to the adolescent measure, but omitted the spanking item, and the sexual touching item. Adult respondents were asked to report the frequency of these abusive behaviors by a parent, foster parent, or adult relative, prior to the age of 18 years. Cronbach's alpha for adult the adult abuse scale was 89 . 
Antisocial behavior was measured by the involvement of the youth or adult in the legal system. Four items were used for adolescents: contact with a probation officer, contact with a substance abuse counselor, spending time in juvenile detention, and spending time in a residential substance abuse treatment program. Cronbach's alpha for the adolescent measure was .64. Three items were used for adult antisocial behavior: arrests within the last six months, a felony conviction, and ever serving time in jail. Cronbach's alpha for the adult measure was .68.

Deviant subsistence strategies were measured by summing five items that addressed how often respondents engaged in activities such as panhandling, selling drugs, shoplifting, burglary, theft, and prostitution to support themselves on streets. Response categories ranged from 1 = never to 5 = always. Cronbach's alphas were .74 for adolescents and .67 for adults.

Victimization was measured with five items involving criminal victimization. Respondents were asked to report the number of times that they had been beaten up, robbed, sexually assaulted, threatened with a weapon, or assaulted with a weapon while on the streets. Response categories ranged from $1=$ never to $4=$ more than 3 times. Cronbach's alphas were .78 for adolescents and .78 for adults.

The difference of proportion test was used to compare adaptive strategies to life on the streets and victimization by age and gender. Path analysis was used to test the model hypothesized in Figure 1. The model was run separately for males and females by age group resulting in four separate analyses.

\section{Results}

\section{Age-Related Differences in Risk of Victimization}

Homeless adolescents were more likely to come from abusive family backgrounds, more likely to be involved in deviant subsistence strategies and more likely to be criminally victimized on the streets than their adult counterparts. As Table 3 indicates, the rates of physical and sexual abuse for homeless adolescents exceeded those for homeless adults in almost every category. Adolescents were almost twice as apt to have been beaten by a parent, slapped by a parent, or hit with an object. The rate of sexual abuse reported by homeless adolescents was two times that reported by homeless adults. Rates of sexual abuse for adolescent females were $10 \%$ higher than those for adult females. Although rates of abuse are consistently higher for adolescents, the rates for both age groups greatly exceeded those reported in the Straus and Gelles (1990) national probability sample. For example. Straus and Gelles reported that only .6\% of their sample of children aged 3-17 years were beaten in the past year (1990, p. 118) compared to our life time reports of $47.7 \%$ of homeless adolescents and $26.3 \%$ of homeless adults.

Table 4 reports frequencies of deviant subsistence strategies and victimization by age groups and gender. The difference of proportion test was used to determine statistically significant differences between age and gender groups. The experience of life on the streets for adolescents was very different from that of adults. Homeless adolescents were much more apt to be involved in deviant subsistence strategies. They were more likely to sell drugs, shoplift, and commit burglary or theft, to survive. Homeless adults were more 
Table 3. Percentage of Adolescent Runaways and Homeless Adults Reporting ever Being Physically or Sexually Abused by Parent, Foster Parent, or Adult Relative

\begin{tabular}{|c|c|c|c|c|c|c|}
\hline \multirow[b]{2}{*}{ Total } & \multicolumn{3}{|c|}{ Adolescents } & \multicolumn{3}{|c|}{ Adults } \\
\hline & $\begin{array}{l}\text { Percent } \\
\text { Males }\end{array}$ & $\begin{array}{l}\text { Percent } \\
\text { Females }\end{array}$ & $\begin{array}{l}\text { Percent } \\
\text { Total }\end{array}$ & $\begin{array}{l}\text { Percent } \\
\text { Males }\end{array}$ & $\begin{array}{l}\text { Percent } \\
\text { Females }\end{array}$ & $\begin{array}{c}\text { Percent } \\
\text { Total }\end{array}$ \\
\hline Type of Abuse* & $(\mathrm{N}=156)$ & $(\mathrm{N}=83)$ & $(\mathrm{N}=73)$ & $(\mathrm{N}=319)$ & $(\mathrm{N}=224)$ & $(\mathrm{N}=95)$ \\
\hline $\begin{array}{c}\text { Threw something at } \\
\text { you in anger }\end{array}$ & 66.7 & 64.6 & 69.0 & 30.7 & 27.2 & 38.6 \\
\hline $\begin{array}{l}\text { Pushed, shoved, or } \\
\text { grabbed you in anger }\end{array}$ & 81.5 & 82.5 & 80.3 & 37.9 & 33.1 & 47.1 \\
\hline Slapped you & 79.7 & 80.5 & 78.9 & 42.8 & 37.2 & 55.2 \\
\hline Spanked you & 74.8 & 75.3 & 74.3 & - & - & - \\
\hline $\begin{array}{l}\text { Hit you with an } \\
\text { object }\end{array}$ & 67.5 & 63.0 & 72.9 & 35.3 & 29.4 & 48.3 \\
\hline Beat you up & 47.7 & 53.8 & 40.8 & 26.3 & 25.6 & 28.4 \\
\hline $\begin{array}{l}\text { Threatened you with } \\
\text { gun or knife }\end{array}$ & 19.2 & 17.5 & 21.1 & 16.0 & 15.6 & 17.0 \\
\hline $\begin{array}{l}\text { Assaulted you with } \\
\text { gun or knife }\end{array}$ & 9.3 & 8.9 & 9.9 & 4.1 & 5.0 & 2.3 \\
\hline $\begin{array}{l}\text { Made a verbal } \\
\text { request for sexual } \\
\text { activity }\end{array}$ & 23.7 & 12.3 & 36.6 & 10.9 & 5.0 & 23.3 \\
\hline $\begin{array}{l}\text { Touched or attempted } \\
\text { to touch you sexually }\end{array}$ & 24.5 & 11.1 & 40.0 & - & - & - \\
\hline $\begin{array}{l}\text { Forced you to engage } \\
\text { in sexual activity }\end{array}$ & 21.7 & 8.6 & 36.6 & 10.1 & 2.8 & 25.6 \\
\hline
\end{tabular}

* Duplicated count, columns do not add to 100 .

likely to use more passive adaptations to street life such as panhandling (not significant) and getting food from dumpsters. Adults were also highly likely to sell blood $(51.7 \%$, not shown), an option not available to minors.

The age differences were fairly consistent by gender. Adolescent females were more likely to be involved in theft than adult females were. Although adolescent females were slightly more apt to report prostituting themselves than were adult women, the difference was not statistically significant. Adolescent males were more likely to be involved in selling drugs, shoplifting, and burglary than their adult male counterparts. Adult homeless males were more likely to panhandle and to get food from dumpsters than were adolescent males.

A general pattern of a greater reliance on deviant subsistence strategies was apparent among males. Adolescent boys were more likely to use deviant subsistence strategies than were adolescent females. Boys were more likely to sell drugs, shoplift, and commit burglary and theft than were girls. Although adolescent females were more apt to report using prostitution to support themselves, the difference was not statistically significant. Similarly, homeless adult males were more apt to panhandle, get food from dumpsters, and commit burglary than their female counterparts. Homeless women were more likely to use prostitution as a means of support than were homeless men. 
Table 4. Frequencies for Deviant Subsistence Strategies and Victimization among Homeless Adolescents and Adults

\begin{tabular}{|c|c|c|c|c|c|c|}
\hline \multirow[b]{2}{*}{$\begin{array}{l}\text { Deviant } \\
\text { Subsistence } \\
\text { Strategies }\end{array}$} & \multicolumn{3}{|c|}{ Adolescents } & \multicolumn{3}{|c|}{ Adults } \\
\hline & $\begin{array}{c}\text { Total } \\
\text { Percent } \\
(\mathrm{N}=156)\end{array}$ & $\begin{array}{l}\text { Males } \\
\text { Percent } \\
(\mathrm{N}=83)\end{array}$ & $\begin{array}{l}\text { Females } \\
\text { Percent } \\
(\mathrm{N}=73)\end{array}$ & $\begin{array}{c}\text { Total } \\
\text { Percent } \\
(\mathrm{N}=319)\end{array}$ & $\begin{array}{c}\text { Males } \\
\text { Percent } \\
(\mathrm{N}=224)\end{array}$ & $\begin{array}{l}\text { Females } \\
\text { Percent } \\
(\mathrm{N}=95)\end{array}$ \\
\hline Sold drugs & $33.4^{\mathrm{a}}$ & $50.6^{\mathrm{b}, \mathrm{d}}$ & 16.7 & 14.7 & $17.5^{\mathrm{c}}$ & 8.4 \\
\hline Panhandled & 26.2 & 26.0 & 26.4 & 30.6 & $37.7^{\mathrm{c}}$ & 14.7 \\
\hline Got food from dumpsters & $7.5^{\mathrm{a}}$ & $6.6^{\mathrm{d}}$ & 8.6 & 31.3 & $40.1^{\mathrm{c}}$ & 11.6 \\
\hline Shoplifted & $62.8^{\mathrm{a}}$ & $68.8^{\mathrm{b}}$ & $55.3^{d}$ & 32.6 & 32.9 & 32.6 \\
\hline $\begin{array}{l}\text { Broke in and took things } \\
\text { from house, store, etc. }\end{array}$ & $32.4^{\mathrm{a}}$ & $44.2^{\mathrm{b}, \mathrm{d}}$ & $19.7^{\mathrm{d}}$ & 9.4 & 13.06 & 1.1 \\
\hline $\begin{array}{l}\text { Took money or something } \\
\text { else from someone } \\
\text { by force }\end{array}$ & $19.2^{\mathrm{a}}$ & $29.1^{b, d}$ & 8.3 & 5.3 & 7.2 & 1.1 \\
\hline Sold sexual favors & 9.4 & 5.2 & 13.9 & 5.9 & $4.0^{c}$ & 10.5 \\
\hline \multicolumn{7}{|l|}{ Victimization } \\
\hline Beaten up & 42.6 & 49.4 & 35.2 & 35.3 & $40.8^{c}$ & 23.2 \\
\hline Robbed & $17.3^{\mathrm{a}}$ & $17.7^{\mathrm{d}}$ & $16.9^{d}$ & 37.8 & 39.5 & 34.7 \\
\hline Raped & 23.2 & $10.1^{\mathrm{b}, \mathrm{d}}$ & $37.5^{\mathrm{d}}$ & 6.6 & $3.1^{\mathrm{c}}$ & 14.7 \\
\hline Threatened with a weapon & $46.4^{\mathrm{a}}$ & $57.0^{\mathrm{b}, \mathrm{d}}$ & $34.7^{\mathrm{d}}$ & 35.9 & $43.0^{c}$ & 20.0 \\
\hline Assaulted with a weapon & $32.71^{\mathrm{a}}$ & $41.8^{\mathrm{b}, \mathrm{d}}$ & $22.5^{\mathrm{d}}$ & 17.5 & $21.5^{c}$ & 8.4 \\
\hline
\end{tabular}

a Significant differences between totals for age groups $(\mathrm{p} \leq .05)$

b Significant differences between genders for adolescents $(\mathrm{p} \leq .05)$

c Significant differences between genders for adults $(\mathrm{p} \leq .05)$

$\mathrm{d}$ Significant differences between age groups by gender $(\mathrm{p} \leq .05)$

Patterns of victimization between homeless adolescents and adults are even more divergent. Homeless adolescents are more at risk for robbery, rape, being threatened with a weapon, and assaulted with a weapon than homeless adults. With the exception of adult women reporting a lower incidence of being beaten up than adult males, there was little difference in risk of being physically beaten between groups. Adolescent males were at greater risk for altercations involving weapons than any other group. Women were at greater risk of sexual assault than were males regardless of age. Adolescent women reported the highest incidence of sexual assault.

In summary, the hypotheses that homeless adolescents would more likely be from abusive families, more likely to be involved in deviant subsistence strategies, and more likely to experience criminal victimization than homeless adults were strongly supported. Patterns of greater reliance on deviant subsistence methods and greater risk of victimization are very clear. Greater rates of child abuse also confirm the expectation that adolescents are on the streets because they are running from something.

\section{Models to Adaptation to Life on the Street}

The proposed social learning model (Figure 1) tested the consequences of an abusive family history on adaptation to homelessness and victimization on the streets. The model hypothesized that a history of abuse in the family would result in a greater likelihood of 
antisocial behavior, which, in turn, would result in a greater likelihood of reliance on deviant subsistence patterns when on the street. Deviant subsistence patterns were predicted to be positively associated with criminal victimization. The bivariate correlations for the variables included in the path models (Table 5) were strongest for adolescent males with all the variables being significantly correlated. Abuse was correlated with victimization for both male and female adolescents, but not for adults. Abuse was strongly correlated with deviant subsistence strategies for all groups. Similarly, deviant subsistence strategies correlated strongly at the zero-order level with victimization for all groups.

Figures 2 and 3 present the results of the fully recursive path analyses for homeless adolescents and adults respectively. Standardized regression coefficients above the lines are for males and coefficients below the lines and in parentheses are for females. The proposed model had greater explanatory power for males than females regardless of age. Although the models for homeless adolescent and adult males explained similar amounts of the variance in victimization (adult males, $\mathrm{R}^{2}=359$; adolescent males, $\mathrm{R}^{2}=367$ ), they differed slightly. For homeless adolescent males, all the paths making up the model were statistically significant. A history of child abuse affected victimization directly and indirectly through antisocial behaviors and participation in deviant subsistence strategies. For the older homeless males, all of the effects of child abuse were indirect, via later antisocial behaviors and deviant subsistence patterns on the streets. An abusive history increased the likelihood of an antisocial history which acted to increase victimization on the streets directly and indirectly through increasing the likelihood of reliance on deviant subsistence strategies.

Table 5. Bivariate Correlations for Path Model

Adults (males above the diagonal, females below the diagonal) $(\mathrm{N}=321)$

\begin{tabular}{lcccc}
\hline & $\begin{array}{c}\text { History of } \\
\text { Abuse }\end{array}$ & $\begin{array}{c}\text { Antisocial } \\
\text { Behaviors }\end{array}$ & $\begin{array}{c}\text { Deviant } \\
\text { Subsistence } \\
\text { Strategies }\end{array}$ & Victimization \\
\hline $\begin{array}{l}\text { History of abuse } \\
\text { Antisocial behaviors }\end{array}$ & .152 & $.242^{* *}$ & $.228^{* *}$ & .121 \\
$\begin{array}{l}\text { Deviant subsistence } \\
\text { strategies }\end{array}$ & $.307^{* *}$ & $.222^{*}$ & $.485^{* *}$ & $.409^{* *}$ \\
$\begin{array}{l}\text { Victimization } \\
\text { Vition }\end{array}$ & .091 & .089 & & $.474^{* *}$ \\
\end{tabular}

Adolescents (males above the diagonal, females below the diagonal) $(\mathrm{N}=156)$

\begin{tabular}{|c|c|c|c|c|}
\hline & $\begin{array}{l}\text { History of } \\
\text { Abuse }\end{array}$ & $\begin{array}{l}\text { Antisocial } \\
\text { Behaviors }\end{array}$ & $\begin{array}{c}\text { Deviant } \\
\text { Subsistence } \\
\text { Strategies }\end{array}$ & Victimization \\
\hline History of abuse & & $.289^{* *}$ & $.465^{* *}$ & $.404^{* *}$ \\
\hline Antisocial behaviors & $.233^{*}$ & & $.490^{* *}$ & $.476^{* *}$ \\
\hline $\begin{array}{l}\text { Deviant subsistence } \\
\text { strategies }\end{array}$ & $.344^{* *}$ & $.332^{* *}$ & & $.493^{* *}$ \\
\hline Victimization & $.244^{* *}$ & .063 & $.508^{* *}$ & \\
\hline
\end{tabular}

${ }^{*} \mathrm{p} \leq .05$

${ }^{* *} \mathrm{p} \leq .01$ 


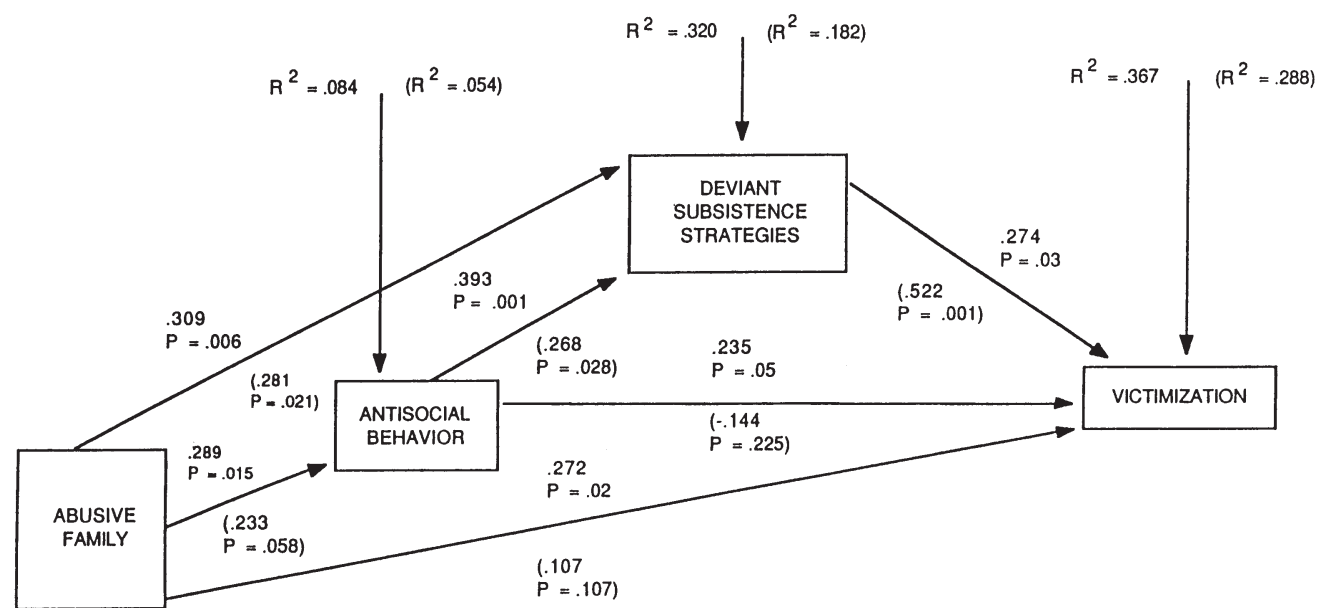

Figure 2. Path Model with Standardized Regression Coefficients for Homeless Adolescents. Coefficients for males are above the lines; coefficients for females are below the lines and in parentheses.

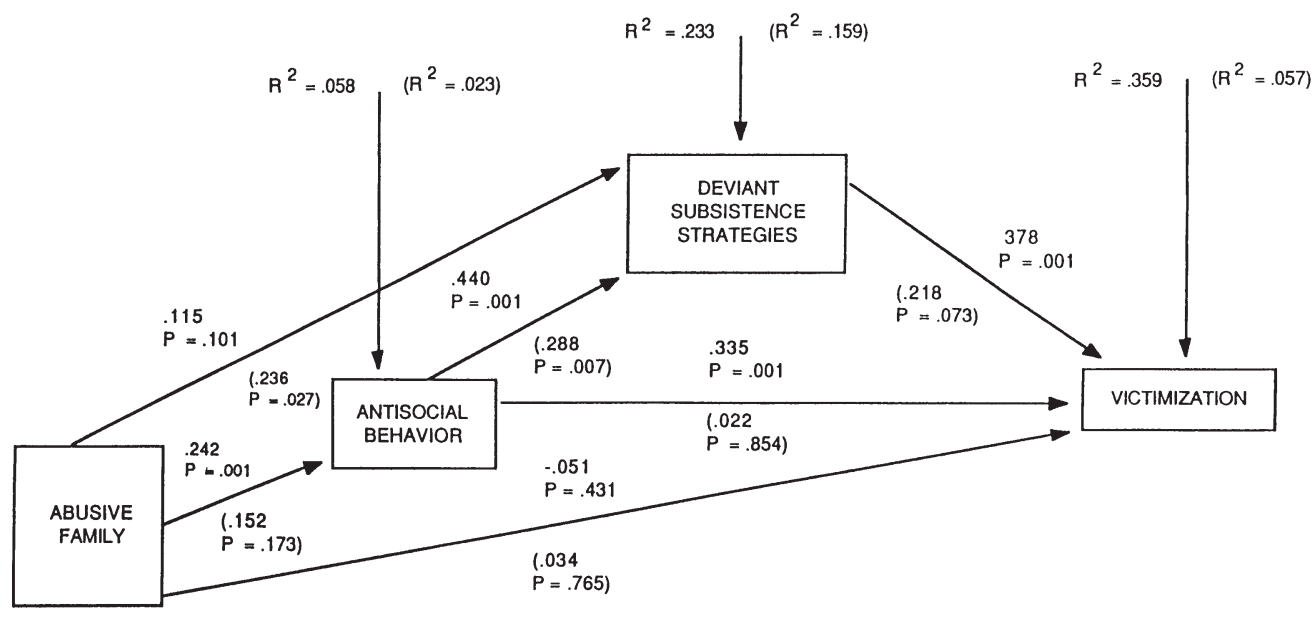

Figure 3. Path Model with Standardized Regression Coefficients for Homeless Adults. Coefficients for males are above the lines; coefficients for females are below the lines and in parentheses.

There were even greater differences between homeless adolescent and adult women. The proposed model explained only about $6 \%$ of the variance in victimization for adult women, but $29 \%$ of the variance for adolescent women. Some of this difference in explanatory power may be accounted for by the characteristics of the adult women in the sample. They were much more likely to be interviewed in shelters than directly on the streets and were much more likely than the other groups to have some sort of financial support. For adult women the effects of a history of child abuse on victimization were conveyed only through the increased likelihood of engaging in deviant subsistence strategies. Deviant subsistence strategies, in turn, had a weak, positive effect on victimization (beta = $.218, \mathrm{p} \geq .073$ ). For adolescent women, a history of abuse within the family contributed 
both to antisocial behavior and deviant subsistence patterns on the streets. All of the effects of abuse and antisocial behavior on victimization were conveyed through deviant subsistence strategies.

In summary, the proposed model indicated that a history of childhood victimization seriously affected adaptation and risk for both homeless adults and adolescents. Two distinct patterns emerged by gender for the effects of early victimization within the family on later adaptation and victimization on the streets. A history of child abuse contributed to a more aggressive adaptation to homelessness among males. For males, an abusive history resulted in a greater likelihood of antisocial behaviors which directly increased the likelihood of further victimization. Antisocial behavior also increased the likelihood of victimization through its positive effects on deviant survival strategies. For women, the effects of abuse were less direct. Neither a history of abuse, nor antisocial behaviors contributed directly to victimization. Rather, an abusive history made it more likely women would participate in deviant subsistence strategies, which increased the likelihood of victimization.

Age differences were primarily evident among homeless women, although the effects of an abusive history were more pervasive for younger males than older males. In general, adolescents were more likely to report an abusive family background, and the effects of abuse were more virulent and pervasive for adolescents than for adults. The results indicated that both early and late victimization characterize the homeless population regardless of age, but that younger homeless people are more likely to be victims both prior to becoming homeless and in their adaptation to life on the streets.

\section{Discussion and Conclusions}

Homeless people are especially at risk for criminal victimization because of the public nature of their daily lives (Hindelang, et al. 1978). In addition to location, the personal resources the homeless person brings to living on the streets and the manner of adaptation affect vulnerability. Our results indicated that a history of abuse and deviant methods of adaptation act to exacerbate potential risk. Abusive histories and adaptive strategies were differentially distributed among homeless individuals based on factors such as the reasons for becoming homeless, and age. Adults were more likely to find themselves homeless for a multiplicity of reasons. Homeless adolescents were more likely to share flight as a common reason for their homelessness.

Although the rates of reported abuse were substantially higher for adolescents than adults, adult homeless people reported rates of abuse much higher than national projections. This finding is congruent with other research regarding backgrounds of adult homeless people (Bassuk \& Rosenberg, 1988; Shinn, Knickman, and Weitzman, 1989; Wood, Valdez, Hayashi, \& Shen, 1990). Goodman (1991) in a small sample of homeless and economically disadvantaged housed women found little difference between the two groups in abusive histories. Both groups, however, had prevalence rates much higher than those in the general population. Wood et al. (1990) found rates of physical and sexual abuse among the homeless portion of their sample similar to those in the present study.

Homeless adolescents in the sample were highly likely to be running from an abusive family environment. The rates of abuse for adolescents were several times those of national projections (Straus \& Gelles, 1990), and were often twice those of the homeless adults. Al- 
though estimates of prevalence of sexual abuse among young people vary widely, the rates of sexual abuse for girls were similar to those reported in other samples of runaway youth (McCormack, Burgess, \& Gaccione, 1986), and greater than the more moderate estimates of sexual abuse in the general population (Finkelhor, 1986). The rates of sexual abuse reported among the runaway adolescent boys were less than that reported in other studies.

The present results are congruent with the considerable evidence that suggests dysfunctional families and abusive parenting result in antisocial behaviors among young people. For example, our findings are similar to those of Dembo et al. $(1989 ; 1992)$ who found that abusive family histories were related to drug use and self-reported delinquency among adolescents surveyed in a juvenile detention center. Similarly, among our sample of runaway adolescents, a history of abuse was strongly related to antisocial behaviors and deviant subsistence strategies on the streets. Although less likely to be from abusive backgrounds, the rates of abuse among homeless adults were also much higher than national projections, and a history of abuse was correlated with deviant subsistence strategies for both adult men and women.

The findings supported our application of Patterson's social learning approach to the development of antisocial behaviors. According to this theoretical approach, child abuse sets a negative chain of events in motion which result in a generalization of aggressive interaction patterns across situations. Such behaviors become self-reinforcing in that aggressive responses evoke aggressive responses from others, so that over time the individual comes to expect aggression in interactions with other people. Early aggressive parenting, provides "basic training" for later antisocial behaviors (Patterson, 1982). In the present research, the effects of such "basic training" were most dramatic for homeless males, explaining over one-third of the variance in victimization on the streets. For adolescent males, a history of abuse increased the likelihood of victimization directly and indirectly through increasing antisocial behaviors and deviant subsistence strategies on the streets. For older males, the effects were more apt to be indirectly transmitted via a history of antisocial behaviors and deviant subsistence strategies when homeless.

The impact of early abuse on victimization of homeless women was somewhat different. Although a history of abuse increased antisocial behavior among adolescent women, such antisocial behavior did not have a direct impact on victimization on the streets. Rather, abuse increased the likelihood of deviant subsistence patterns among young women both directly and indirectly through a history of antisocial behaviors. For both adolescent and adult women, all of the effects of early abuse were transmitted through deviant subsistence strategies. Because adult women currently living in battered women's shelters were not included in our sample of homeless adults, the extent of adult women from abusive backgrounds may be underestimated.

Although the effects of an abusive history were apparent for both males and females, the patterns diverged. For males, the effects increased aggressive or antisocial interaction and actively place them at risk. For females, the pattern was more tied to situations and subsistence strategies that increased the likelihood of victimization. The data also indicated that the effects of early abuse, although persistent, may moderate over time. The effects for adults were less direct and severe than for adolescents.

Factors besides a history of abuse also played significant roles in increasing risk. Regardless of location, there is a consistent inverse relationship between victimization and age. Young people typically are more at risk for criminal victimization than adults. 
This age difference certainly carries over into these high risk groups of adolescents and adults. Age also served to limit the number of adaptive strategies available for adolescents. While a few legitimate, though meager, means of support were available for homeless adults, these were much less accessible for youth. There are no institutionalized financial benefits available to aid this group because they are not supposed to be financially independent at this stage of life. Their status as minors and as runaways made it difficult to use such legitimate strategies as selling blood or seeking low level employment to get by. Since deviant subsistence strategies are highly related to victimization, adolescents are at increased risk on the streets because they simply have fewer options for self support.

Our samples of homeless young people and adults limit the generalizability of the results in two ways. First, the samples were not systematically stratified by type of homeless person. Although the data were collected over time by street workers familiar with the street culture of this moderately sized Midwestern city, there is the possibility that adults in shelters are over-represented. Our finding that most of the adult women were residing in shelters, therefore, may be an artifact of our sampling frame. Second, characteristics of homeless populations vary regionally. It is likely, the over-representation of shelter women may be characteristic of this particular city or region. As noted, we know very little about homeless populations in less urban states. Replications of our findings in similarly sized cities in various geographical regions are needed to corroborate the results.

In summary, these findings suggest that besides the greater vulnerability due to location, adaptive strategies affect risk among homeless individuals. Age and early victimization places young people at special risk on the streets. With fewer legitimate means of support available to them, and a greater propensity for antisocial behaviors and deviant subsistence strategies, homeless adolescents tend to be at greater risk of victimization than homeless adults. Early victimization within the family increases the risk of later victimization for young and old alike.

The effects of abuse are lasting and damaging for both age groups. Early abuse sets a pernicious chain of events and behaviors in motion, that continue to place homeless individuals a risk for further victimization via a pattern of increased antisocial behaviors and deviant subsistence strategies on the street. Homeless individuals find little on the streets that will break the chain. The present findings provide evidence that a substantial proportion of both adolescent and adult homeless persons come from seriously dysfunctional family backgrounds. Although the damage from dysfunctional families may be difficult to remediate, programs that provide early intervention and support to prevent the downward drift to deviant subsistence strategies for young people who find themselves on the street may reduce the cumulative effects of multiple victimizations and exploitation. Future research dealing with both diagnosis and interventions with homeless individuals should consider the lasting consequences of these early experiences.

\section{References}

Bassuk.E. (1986). The mental health needs of homeless persons. San Francisco: Jossey-Bass.

Bassuk, R., \& Rosenberg, L. (1988). Why does family homelessness occur: A case-control study. American Journal of Public Health, 7, 783-788. 
Baxter, E., \& Hopper, K. (1984). Troubled on the streets: The mentally disabled homeless poor. In J. A. Talbott, (Ed.), The chronic mental patient: Five years later (pp. 50-72). Orlando FL: Grune and Stratton.

Brennan, T., Blanchard, F., Huizinga, D., \& Elliott, D. (1975). The incidence and nature of runaway behavior. Springfield, VA: U.S. Department of Commerce, National Technical Information Service.

Committee on Health Care for Homeless People. (1988). Homelessness, health, and human needs. Washington, D.C.: National Academy Press.

Dembo, R., Williams, L., La Voie. L., Berry. E., Getreu, A., Wish, E., Schmeidler, J., \& Wasburn, M. (1989). Physical abuse, sexual victimization, and illicit drug use: Replication of a structural analysis among a new sample of high-risk youth. Violence and Victims, 4, 121-128.

Dembo, R., Williams, L. Schmeidler, J., Berry, E., Wothke, W., Getreu, A., Wish E., \& Christensen, C. (1992). A structural model examining the relationship between physical child abuse, sexual victimization, and marijuana/hashish use in delinquent youth: A longitudinal study. Violence and Victims, 7, 41-62.

Department of Housing and Urban Development, A report to the secretary on the homeless and emergency shelters (Washington. D.C., May, 1984).

Dishion, T., \& Loeber, R. (1985). Adolescent marijuana and alcohol use: The role of parents and peers revisited. American Journal of Drug and Alcohol Abuse, 77,11-25.

Finkelhor, D. (1986). A source book on child sexual abuse. Beverly Hills, CA: Sage.

Goodman, L. (1991). The prevalence of abuse among homeless and housed poor mothers: A comparison study. American Journal of Orthopsychiatry, 6,498-500.

Hersch, P. (1988). Coming of age on city streets. Psychology Today, January, pp. 28-37.

Hindelang, M., Gottfredson, M., \& Garafola. J. (1978). Victims of crime: An empirical foundation for a theory of personal victimization. Cambridge, MA: Ballinger.

Hindelang, M., Hirschi, T., \& Weiss, J. (1981). Measuring delinquency. Beverly Hills: Sage.

Hope, M., \& Young, J. (1986). The faces of homelessness. Lexington, MA: Lexington Books.

Hopper, K., \& Hamberg, J. (1986). The making of America's homeless: From skidrow to new poor, 1945-1984. In B. Hartman \& A. Meyerson, (Eds.), Critical perspectives on housing (pp. 12-40). Philadelphia: Temple University Press.

Jahiel, R. (1987). The situation of homelessness. In R. Bingham, R, Green, \& S. White, (Eds.), The homeless in contemporary society (pp. 99-118). Newbury Park, CA: Sage.

Janus, M., McCormack, A. Burgess. A., \& Hartman, C. (1987). Adolescent runaways: Causes and consequences. Lexington, MA: Lexington Books.

McCormack, A., Burgess, A., \& Gaccione, P. (1986). Influence of family structure and financial stability on and sexual abuse among a runaway population. International Journal of Sociology of the Family, 76, 251-262.

Momemi, J. (1989). Homelessness in the United States, Vol. 1: State surveys. New York: Greenwood Press.

Nye, F., \& Edelbrock. C. (1980). Some social characteristics of runaways. Journal of Family Issues, 7, 147-150.

Patterson, G. (1982). Coercive family process. Eugene, OR: Castilia.

Patterson, G. (1986). Performance models for antisocial boys. American Psychologist, 47.432-444.

Patterson, G., \& Bank, L. (1987). Some amplifying mechanisms for pathological processes in families. Paper presented at the Minnesota Symposium on Child Psychology. 
Patterson, G., Dishion, T., \& Bank, L. (1984). Family interaction: A process model of deviancy training. Aggressive Behavior, 70, 253-267.

Patterson, G., \& Stouthammer-Loeber, M. (1984). The correlation of family management practices and delinquency. Child Development, 55, 1299-1307.

Peroff, K. (1987). Who are the homeless and how many are there? In R. Bingham, R. Green, \& S. White (Eds.), The homeless in contemporary society (pp. 99-118). Newbury Park, CA: Sage.

Roper, R. (1988). The invisible homeless. New York: Insight Books.

Shinn, M., Knickman, J., \& Weitzman, B. (1989). Social relationships and vulnerability to becoming homeless among poor families. American Psychologist, 46, 1180-1187.

Simons. R., Whitbeck, L., \& Bales. A. (1989). Life on the streets: Victimization and Psychological distress among the adult homeless. Journal of Interpersonal Violence, 4, 4S2-5Q1.

Simons, R., \& Whitbeck, L. (1991). Sexual abuse as a precursor to prostitution and victimization among adolescent and adult homeless women. Family Issues, 72, 361-379.

Stefl, M. (1987). The homeless in contemporary society. In R. Bingham, R. Green, \& S. White, (Eds.), The homeless in contemporary society (pp. 46-63). Newbury Park, CA: Sage.

Straus, M., \& Gelles R. (1990). Physical violence in American families. New Brunswick, NJ: Transaction Publishers.

Weitzman, B., Knickman, J., \& Shinn. M. (1990). Pathways to homelessness among New York City families. Journal of Social Issues, 46, 125-140.

Whitbeck, L., \& Simons, R. (1990). Life on the streets: The victimization of runaway and homeless adolescents. Youth and Society, 22, 108-125.

Wood, D., Valdez, R., Hayashi, T., \& Shen, A. (1990). Homeless and housed families in Los Angeles: A study comparing demographic, economic, and family function characteristics. American Journal of Public Health, 80, 1049-1052.

The authors gratefully acknowledge the helpful advice and cooperation of the staff at the Des Moines Center for Homeless, Runaway and Missing Youth, and Andrew Bales, Director of Door of Faith Mission, Des Moines, IA. 